\title{
Including protein yield and mastitis resistance in dairy cattle breeding goal optimizes response to selection
}

\author{
C.B. Sagwa", T.O. Okeno \& A.K. Kahi \\ Animal Breeding and Genomics Group, Department of Animal Science, Egerton University, P.O. Box 536, 20115, \\ Egerton, Kenya
}

(Received 1 October 2018; Accepted 18 October 2019; First published online 31 January 2020)
Copyright resides with the authors in terms of the Creative Commons Attribution 4.0 South African License.
See: http://creativecommons.org/licenses/by/4.0/za
Condition of use: The user may copy, distribute, transmit and adapt the work, but must recognize the authors and the South African Journal of Animal Science.

\begin{abstract}
Selection response from a two-tier nucleus breeding scheme using the current Kenyan breeding goal was compared with an alternative that also accounts for protein yield (PY) and mastitis resistance (MR). The economic value for PY was estimated using a bio-economic model. For mastitis resistance, like other disease resistance traits, the economic value cannot be estimated with profit equations because they have multi-fold effects on input and output, which affects profitability. Therefore, selection index methodology was used. Somatic cell count (SCC) was used as an indicator trait for MR. The ZPAN computer program was used to model the breeding schemes and evaluate response to selection. The alternative breeding goal, which included PY and MR, realized additional KES358.48, 613.55, and 613.65 in annual genetic gain, returns and profit per cow per year, respectively, compared with the current breeding goal. Economic values for PY and MR were KES778.99 and -2364, respectively. Relative economic values for milk yield (MY, $\mathrm{kg}$ ), fat yield ( $F Y, k g)$, protein yield (PY, kg), MR, calving interval ( $\mathrm{Cl}$, days), preweaning daily gain (DG, g/day), postweaning daily gain (PDG, g/day), live weight (LW, kg), preweaning survival (SR1, \%), postweaning survival (SR2, \%), and length of productive life (PLT, days) were 23 689.80, 4 146.77, 34 665.50, -992.88, 33.66, 62.40, 159.80, 391.94, 987.04, 4 474.37, and 7.56, respectively. This implies that including milk quality traits such as PY in the breeding goal would optimize response to selection in dairy cattle production.
\end{abstract}

Keywords: breeding objective, economic values, genetic evaluation, milk quality, traits, udder health

\#Corresponding author: c.bsagwa@yahoo.com

\section{Introduction}

The production of high-quality milk is necessary to sustain a profitable dairy industry (Ruegg \& Pantoja, 2013). The market demands better quality and, in particular, more healthful products that are produced by healthy animals. Milk quality, as reflected by its technological properties, affects milk processing and ultimately product quality (Barbano et al., 2006; Parna et al., 2012; Zhao et al., 2014). The milk pricing system is the most important factor that affects the relative weightings of milk volume, fat, and protein percentages, clinical mastitis and somatic cell count (SCC) in the breeding goal (Wolfova et al., 2007). Milk payment in Kenya is currently based on volume. However, this is likely to shift towards quality owing to commercialization of the dairy sector. Somatic cell count, protein and butter fat contents are the major characteristics that are used to quantify milk quality (Ruegg \& Pantoja, 2013). Premium prices are awarded for milk that exceeds certain thresholds, and penalties are imposed on milk that falls below minimum quality thresholds. Thus, SCC and PY directly affect revenue from sale of milk (Nightingale et al., 2008). In qualitybased markets, increased PY typically results in positive marginal returns, and the value of protein is usually greater than that of other milk components (Banga et al., 2011). The SCC is routinely used to identify subclinical mastitis with a somatic cell count of less than $200000 \mathrm{cells} / \mathrm{ml}$ indicating a healthy mammary quarter (Ruegg \& Pantoja, 2013). A greater SCC is an indirect indicator for mastitis in dairy cattle.

Mastitis is the costliest disease in dairy cattle production, resulting in heavy economic losses annually (Berry et al., 2011). In the tropics, these losses have been valued at US $\$ 38.00$ per cow per lactation (Mungube et al., 2005). The incidence of mastitis in Kenya is extremely high and over $60.7 \%$ of dairy cows in smallholder production systems produce milk with SCC that is greater than $200000 \mathrm{cells} / \mathrm{ml}$ (Kashongwe et al., 2017). This implies most smallholder farms incur losses that are attributed to reduced MY and quality, 
discarded milk during the withdrawal period after the use of therapeutic drugs, veterinary costs, increased culling, and occasional mortality (Omore et al., 1999; Mungube et al., 2005). Previous attempts to overcome this challenge through conventional strategies such as improved udder hygiene and treatments have not been successful (Omore et al., 1999). Therefore, alternative strategies are needed. Breeding for resistance to mastitis has been proposed as an alternative for various reasons. First, animals that are resistant to mastitis may not be afflicted with the disease and therefore would not incur the economic losses. Second, breeding for resistant animals ensures animal welfare concerns and prevents traces of drugs residues in milk. Lastly, animals that are genetically resistant to disease pass their genes to their offspring, and therefore the improvement is progressive and cumulative after each generation. Breeding for resistance requires the inclusion of the disease indicator trait in the breeding goal (Pfeiffer et al., 2015).

The current dairy cattle breeding goal in Kenya (Kahi \& Nitter, 2004) does not account for either protein yield or mastitis resistance. Inclusion of milk quality traits in the dairy cattle breeding goal is an inexpensive and sustainable strategy to improve milk quality. Therefore, there is a need to include PY and MR in the breeding goal for dairy cattle in Kenya. Their inclusion requires estimation of the associated economic values. These economic values are currently lacking under Kenyan production conditions. Thus, the first objective of this study was to derive economic values for PY and MR using SCC as an indicator trait. Having realized the first objective, predicted response to selection for the current breeding goal was compared with that which may result from implementation of a breeding goal which includes PY and MR.

\section{Materials and Methods}

The computer program ZPLAN (William et al., 2008) was used to compare response to selection that was realized in a closed two-tier nucleus breeding system using the current breeding goal with an alternative breeding goal that included PY and MR for dairy production in Kenya. The current breeding goal, in which marketing of milk is based on volume, was used as the base scenario. The alternative breeding goal foresaw the marketing of milk based on its quality. Hence, PY and MR were introduced in the breeding goal. The breeding goals were compared based on economic and genetic gains per cow per year.

Two breeding goals were considered in the current study. The first considered the current dairy cattle breeding goal in Kenya. The traits in this breeding goal included MY, FY, age at first calving (AFC, days), $\mathrm{Cl}$, DG, PDG, LW, SR1, SR2, and PLT. The current breeding goal $(H)$ is:

$H=M Y * v_{1}+F Y * v_{2}+D G * v_{3}+P D G * v_{4}+L W * v_{5}+C I * v_{6}+A F C * v_{7}+S R 1 * v_{8}+S R 2 * v_{9}+P L T * v_{10}$

and the alternative breeding goal $\left(H^{\prime}\right)$ which includes PY and MR in addition to all the traits in the current breeding goal is:

$$
H^{\prime}=H+P Y * v_{11}+M R * v_{12}
$$

The first requisite for inclusion of a trait in the breeding goal is estimation of its economic value (Hazel, 1943). The economic values for traits in the current breeding goal in Kenya have been estimated (Kahi \& Nitter, 2004). However, the economic values for MR and PY have not been estimated. The economic value for MR, like other disease resistance traits, cannot be estimated with profit equations because it has multifold effects on input and output, all of which affect profitability (Sivarajasingam, 1995). Nielsen et al. (2005) described a method for estimating economic value for MR based on selection index methodology (Hazel, 1943; Wagenaar et al., 1995). In this method, for a given set of assumptions, the breeding goal is matched to the expected responses in production traits, and responses in these traits are maximized relative to overall gains. The economic value for mastitis resistance was estimated relative to MY. Somatic cell count was used as the indicator trait of mastitis resistance due to its large positive genetic correlation (0.7) with mastitis (Carlen et al., 2004). Therefore, the assumption was that animals were selected for increased MY and reduced SCC. The computer program SIP (Wagenaar et al., 1995) was used to compute the economic value for SCC. The phenotypic standard deviations, heritability estimates, phenotypic and genetic correlations for MY and SCC were obtained from Pfeiffer et al. (2015) and are presented in Table 1.Genetic responses to selection for traits in the breeding goal were computed as:

$$
S R_{T}=\frac{\sigma_{I T}}{\sigma_{I}} * i
$$

where: $S R_{T}=$ the trait-specific selection response in monetary units; $\sigma_{I T}=$ covariance between index and trait in the breeding goal $T, \sigma_{I}=$ standard deviation of the index; and $i=$ selection intensity. 
Table 1 Economic value in Kenyan shillings, phenotypic standard deviations, heritability estimates, and the phenotypic and genetic correlations of milk yield with somatic cell count

\begin{tabular}{lccccc}
\hline Traits & economic value & phenotypic SD & $\begin{array}{c}\text { heritability } \\
\text { estimate }\end{array}$ & $\begin{array}{c}\text { Phenotypic } \\
\text { correlation }\end{array}$ & $\begin{array}{c}\text { Genetic } \\
\text { correlation }\end{array}$ \\
\hline Milk yield, $\mathrm{kg}$ & 43 & 120.80 & 0.30 & -0.02 & -0.03 \\
Somatic cell count & - & 0.05 & 0.09 & & \\
\end{tabular}

\section{US $\$ 1=\mathrm{KES} 100$}

This study used a data simulation approach to derive an economic value for PY in dairy cattle. Simulation models have been used to predict economic values for traits in the breeding goals for meat sheep (Kosgey et al., 2003), dairy cattle (Kahi \& Nitter, 2004), beef cattle (Rewe et al., 2006) and pigs (Mbuthia et al., 2015) that are produced in the tropics. The model expressed profit through grouping terms by class of cattle and calculated revenue and costs per cow per year. In general, the model predicted profitability as follows:

$$
P=R-C
$$

where: $P, R$ and $C=$ profit, revenue and costs per cow per year in Kenyan shillings, respectively. Total revenue was calculated as:

$$
R=R_{\text {male calves }}+R_{\text {culled heifers }}+R_{\text {culled cows }}+R_{\text {milk }}
$$

where: $R_{\text {male calves }}=$ revenue from sale of male calves; $R_{\text {culled heifers }}=$ revenue from sale of culled heifers; $R_{\text {culled cows }}=$ revenue from sale of culled cows; and $R_{\text {milk }}=$ revenue from sale of milk. Total cost was computed as:

$$
C=C M_{\text {male calves }}+C F_{h}+C H_{h}+C R_{h}+C L_{h}+C M_{h}+C F_{c}+C H_{c}+C R_{c}+C L_{c}+C M_{\text {milk }}+C M_{c}+F I X C
$$

where $C M=$ marketing cost; $C H=$ health care cost; $C R=$ husbandry cost; $C L=$ labour cost; $C M=$ marketing cost; and the subscripts $h$ and $c$ denote heifers and cows respectively.

The economic values were computed as:

$$
E V=\Delta P / \Delta T
$$

where: $\Delta P=$ change in profit resulting from after a unit increase in the trait of interest and $(\Delta T)=$ marginal change in the trait of interest after a unit increase.

Estimates of the phenotypes that were used to compute economic values for traits in the breeding goal are presented in Appendix table 1. They were grouped into biological and nutritional variables that were obtained from various studies in Kenya and the tropics (Kahi \& Nitter, 2004; Kahi et al., 2004; Ilatsia et al., 2011). The management variables and assumed costs for farm produce and services are presented in Appendix table 2.

A population of 50000 cows that were distributed in the two tiers was simulated. The top tier (nucleus) consisted of 2500 cows with the greatest genetic merit, while the remaining $95 \%$, which constituted the lower tier, were deemed the commercial population. The biological and economic parameters that were used in the current study were obtained from previous studies on dairy cattle in Kenya (Kahi \& Nitter, 2004; Kahi et al., 2004; Ilatsia et al., 2011). The selection pathways included sires to breed sires (SS) and dams (SD) and dams to breed sires (DS) and dams (DD). Each selection group had different sources of information for traits in the breeding goal. The information sources for SS and SD were records on individual, sire, dam, and dams of the sire and dam, while those for DS and DD were records on the individual, dam, sire, all female paternal half sibs of the dam and sire, dams of the sire and dam.

Genetic and phenotypic parameters for the selection criteria and traits in the aggregate genotype are required to compute composition and accuracy of selection indices and to obtain accurate expected breeding values (Ilatsia et al., 2011; Visentin et al., 2017).It is important that traits in the breeding objective should be heritable and have variation, and that their phenotypic and genetic correlations with the traits in the selection criteria should be known (Rewe et al., 2006). Estimates of heritability and genetic and phenotypic correlations for traits in the breeding objective from various studies are presented in Appendix table 3. 
Genetic parameters are a characteristic of the population in which they were estimated, and may change overtime due to selection and management decisions (Missanjo et al., 2013). Production traits (MY, FY, LW) are highly heritable than functional traits (AFC, Cl, DG, SR1, SR2, and PLT) and more correlated. Production and functional traits are more correlated to their related production and functional traits. For example, MY and FY are both highly genetically and phenotypically correlated between themselves. The low heritability values for reproductive and survival traits suggest that they are more influenced by the environment.

The two breeding goals were simulated and evaluated by a deterministic approach using the computer program ZPLAN version z10 (William et al., 2008). The ZPLAN program uses biological, statistical and economic parameters to calculate the annual genetic gain for the breeding objective, genetic gain for single traits, and returns on investment adjusted for costs using gene flow and selection index methodology. Profits were calculated for five generations, which is equivalent to a 25 -year investment period. The effect of only one round of selection was considered. The effect of inbreeding was not considered in the prediction of genetic gain, and parameters and selection strategies remained unchanged over the investment period. The current breeding goal, in which marketing of milk is based on volume, was used as the base scenario. The alternative breeding goal was that in which marketing of milk is based on quality. Hence two additional milk quality traits, namely PY and MR, were introduced in the breeding goal. The breeding goals were compared based on the economic and genetic gain per cow per year.

All the breeding values were predicted using best linear unbiased prediction by fitting a multivariate animal model to the phenotypes. The model was computed as:

$$
y=X b+Z a+e
$$

where: $y=$ the vector of phenotypes; $b=$ vector of fixed effects; $a=$ vector of random animal effects; $e=$ vector of residual errors, and $X$ and $Z$ are incidence matrices relating the observations to the fixed effects and animals, respectively. The distribution of phenotypes was assumed to be:

$$
\left[\begin{array}{l}
a \\
e
\end{array}\right] \sim N\left(0 ;\left[\begin{array}{cc}
G \otimes A & 0 \\
0 & R \otimes I
\end{array}\right]\right)
$$

where: $G$ denotes the additive genetic (co)variance matrix for traits in the breeding goal; $A$ denotes the numerator relationship matrix among all animals; $R$ denotes the (co)variance matrix for traits in the breeding goal; and $I$ is an identity matrix of rank equal to the number of animals.

The economic returns were determined based on profitably per cow in each breeding system. The profitability per cow was estimated as:

$$
\pi=\sum_{t=0}^{25}\left(\frac{R_{t}-C_{t}}{(1+r)^{t}}\right)
$$

where the planning horizon is 25 years, $R_{t}=$ the annual return from genetic improvement calculated as realized genetic gain per cow per year; $C_{t}=$ the annual cost of genetic improvement including the fixed and variable costs; and $r=$ the discount rate.

A discount rate of $5 \%$ has been recommended when evaluating animal breeding programmes (Berry et al., 2006), and was adopted in the current study. Variable costs are presented in Appendix table 2. These included costs that were directly related to performance and pedigree recording. Fixed costs were those that were incurred in one round of selection, and were the overhead costs of running the nucleus of 2500 cows. The average time at which fixed costs occurred was assumed to be the mean generation interval. Variable and fixed costs affect only the profit, and not the genetic response. The interest rates for returns (8\%) and costs (6\%) were based on current marketing conditions in Kenya.

\section{Results and Discussion}

The objective of this study was to compare the response to selection that was realized in a closed twotier nucleus breeding system that utilized the current breeding goal with an alternative that also accounted for milk quality traits in the dairy cattle. The findings demonstrate that including milk quality traits in the current breeding goal was not only economically viable, but also increased annual genetic gain. The magnitude of the change of response to selection when the alternative breeding goal was adopted, however, depended on the economic value of milk quality traits that were included in the breeding goal and the accuracy of selection. 
Responses to selection in terms of annual genetic gain, returns, costs and profit per cow per year in the current and alternative breeding goals are presented in Table 2. The alternative breeding goal, which included PY and MR, realized an additional KES358.48, 613.55 and 613.65 in annual genetic gain, returns and profit per cow per year, respectively, compared with the current breeding goal. Including these two traits in the breeding goal did not affect the cost of production.

Table 2 Annual genetic gain, returns, costs and profit per cow for the current and alternative breeding goals in Kenyan shillings

\begin{tabular}{lccc}
\hline \multirow{2}{*}{ Parameters } & \multicolumn{2}{c}{ Breeding goals } & Variance in response \\
\cline { 2 - 3 } & CBG & ABG & \\
\hline Annual genetic gain & 301.42 & 659.90 & 358.48 \\
Returns per cow & 1491.39 & 2104.94 & 613.55 \\
Costs per cow & 181.26 & 181.15 & -0.11 \\
Profit per cow & 1310.14 & 1923.79 & 613.65 \\
\hline
\end{tabular}

CBG: current breeding goal; ABG: alternative breeding goal

$(1 \mathrm{US} \$=$ KES100.00)

The annual genetic gains for individual traits in the two breeding goals are presented in Table 3 . Generally, the response to selection for most of the individual traits in the breeding goal followed the same trend as those of economic returns. The genetic gains for most traits in the alternative breeding goal were higher than those in the current breeding goal. Productive traits such as MY, FY and PY increased by 3.3, 0.01 and 0.1 units, respectively, when an alternative breeding goal was adopted. On the other hand, PDG increased by 0.09 units while DG and LW decreased by 1.78 and 0.02 , units, respectively. The CI and PLT decreased by 0.03 and 0.10 days, respectively, while AFC increased by 0.83 days. The level of SCC remained constant at -0.0002 cells per unit.

Table 3 Annual genetic gains for individual traits resulting from selection based on the current and alternative Kenyan breeding goals for dairy cattle

\begin{tabular}{llrcc}
\hline Trait & \multicolumn{3}{c}{ Breeding goals } & Anits \\
Milk yield & $\mathrm{Kg}$ & CBG & ABG & $\begin{array}{c}\text { Difference in response } \\
\text { to selection }\end{array}$ \\
Fat yield & $\mathrm{Kg}$ & 20.0400 & 23.5400 & 3.50 \\
Protein yield & $\mathrm{Kg}$ & 0.7700 & 0.7800 & 0.01 \\
Mastitis resistance & $\mathrm{Cells} / \mathrm{ml}$ & 0.3700 & 0.4700 & 0.10 \\
Age at first calving & Days & -0.0002 & -0.0002 & - \\
Calving Interval & Days & -2.54 .000 & -1.7100 & -4.25 \\
Pre-weaning daily gain & $\mathrm{Kg}$ & 0.1100 & 0.0800 & -0.03 \\
Post-weaning daily gain & $\mathrm{Kg}$ & 4.5700 & 2.7900 & -1.78 \\
Live weight & $\mathrm{Kg}$ & -0.0100 & 0.1000 & 0.09 \\
Productive lifetime & Days & 0.2300 & 0.2100 & -0.02 \\
& & 1.2000 & 1.1000 & -0.10 \\
\hline
\end{tabular}

CBG: current breeding goal; ABG: alternative breeding goal

The economic values of PY and MR were +779.0 and -2364.0 , respectively. The economic values for the other traits in the proposed breeding goal remained unchanged. These findings provide vital information that is a prerequisite for the inclusion of PY and MR in the current dairy cattle breeding goal in Kenya. 
Standardized relative economic values are important in comparing the proportionate contribution of each trait in the breeding goals. The relative economic values were standardized relative to protein yield and presented in Table 4.

Table 4 Economic values, genotypic standard deviation and relative economic values for traits in the alternative Kenyan breeding goal for dairy cattle

\begin{tabular}{lrrrr}
\hline Trait & Economic value & Genetic SD & $\begin{array}{c}\text { Relative } \\
\text { economic value }\end{array}$ & $\begin{array}{c}\text { Proportional } \\
\text { contribution, \% }\end{array}$ \\
\hline Milk yield (kg) & 16.05 & 1476.00 & $23,689.80$ & 34.03 \\
Fat yield (kg) & 79.44 & 52.20 & $4,146.77$ & 5.96 \\
Protein yield (kg) & 779.00 & 44.50 & $34,665.50$ & 49.80 \\
Mastitis resistance (cells/mL) & -2364.00 & 0.42 & -992.88 & 1.43 \\
Age at first calving (days) & -2.72 & & & \\
Calving interval (days) & 2.65 & 12.70 & 33.66 & 0.05 \\
Pre-weaning daily gain (\%) & 1.04 & 60.00 & 62.40 & 0.09 \\
Post weaning daily gain (g/day) & 3.40 & 47.00 & 159.80 & 0.23 \\
Live weight (kg) & 7.95 & 49.30 & 391.94 & 0.56 \\
Pre-weaning survival rate (\%) & 9.96 & 99.10 & 987.04 & 1.42 \\
Post-weaning survival rate (\%) & 45.15 & 99.10 & 4474.37 & 6.43 \\
Productive lifetime (days) & 0.07 & 108.00 & 7.56 & 0.01 \\
\end{tabular}

Standardized economic values reflect the relative importance of the traits. Protein yield is the most important trait. Milk yield and FY are $32 \%$ and $89 \%$ less valuable than protein, respectively. The contribution of other traits relative to protein yield was basically low at 1-3\% for MR, LW and SR2. The other traits such as Cl, DG, PDG, and PLT had a contribution of less than zero in comparison with protein yield.

The findings for the current study confirm the authors' premise that accounting for milk quality traits in the breeding goal of dairy cattle in Kenya would improve response to selection. The realization of additional $118.9,21.04$ and $46.84 \%$ in annual genetic gain, returns to selection and profitability, respectively (Table 2), in the alternative breeding goal was a clear demonstration that including PY and MR in the current breeding goal was beneficial. Similar trends were observed in the individual traits (Table 3).For instance, increased response to selection was realized in MY, FY and PY, when PY and MR were accounted for in the alternative breeding goal.

The increase in response to selection in the alternative breeding goal could be attributed to three reasons. First, previous studies demonstrated a strong positive genetic and phenotypic correlation between MY, FY, and PY in dairy cattle (Miglior et al., 2009). This implies that an increase in response to selection in MY and FY would contribute to increased response to selection in PY. Second, greater accuracy of selection that was attributed to the additional information from PY and MR in the breeding goal contributed to the increased response to selection. Since PY and MR were correlated with other traits in the breeding goal, the information they added had a positive effect on response to selection (Van Grevenhof et al., 2012). Third, PY and MR had relatively large economic values. The inclusion of traits with large economic values in the breeding goal has a significant effect on response to selection based on the direction of economic value. This was evident in the current study. Protein yield had positive large economic value and therefore realized $54.3 \%$ more response to selection compared with its correlated response in the current breeding goal. On the other hand, the response to selection for MR in the alternative breeding goal was similar to that observed in the current breeding goal because of the negative economic value for indicator trait SCC.

The constant response to selection that was obtained when MR was included in the alternative breeding goal confirms that selection for disease resistant traits is not easy. This could be because of low heritability of the indicator trait and difficulty in measuring MR (Carlen et al., 2004). This implies that MR could be better managed through improved management to reduce the accumulation of pathogens that cause mastitis in dairy cattle rather than through breeding. In the current study, the inclusion of MR in the breeding goal increased the response to selection by only KESO.44, 2.53, and 2.04 for monetary gains, returns to selection, and profitability per cow per year, respectively. The corresponding increases that were attributed to inclusion of PY in the breeding goal were 358.48, 613.55, and 1338.26. This implies that it 
would be economical to include PY in the breeding goal and observe for dairy cattle management practices to reduce or minimize occurrence of mastitis incidences in the herd.

\section{Conclusions}

Inclusion of PY in the breeding goal increased genetic and economic response to selection. On the other hand, inclusion of MR produced minimal change in the economic response to selection. Inclusion of PY in the breeding goal and improvement in environmental management would result in dairy cattle that not only produce high quality milk, but are also resistant to mastitis. The superior genetic materials of the resultant genotypes could be disseminated in the dairy cattle population through structured breeding systems. The benefit of this is fourfold, namely improved milk quality, animal health and welfare, access to export market and economic status of the dairy industry players.

\section{Authors' Contributions}

TOO designed the project. CBS did data collection, simulation and statistical analysis. Writing of the manuscript was done by CBS and TOO. Revision of the results and manuscript was done by AKK.

\section{Conflict of interest Declaration}

The authors declare that there is no conflict of interest.

\section{Acknowledgement}

The authors thank (iLINOVA) Innovation for the Livestock industry. A project on Strengthening Capacity for Participatory Management of Indigenous Livestock to foster Agricultural Innovation in Eastern, Southern and Western Africa (FED/2013/330-246), for their financial support.

\section{References}

Banga, C., Neser, F., Van der Westhuizen, J. \& Garrick, D., 2011. Economic values for dairy production traits under different milk payment systems in South Africa. S. Afr. J. Anim Sci. 40, 112-115.

Barbano, D.M., Ma, Y. \& Santos, M.V., 2006. Influence of raw milk quality on fluid milk shelf life. J. Dairy Sci. 89, E15E19.

Berry, D.P., Madalena, F.E., Cromie, A.R. \& Amer, P.R., 2006. Cumulative discounted expressions of dairy and beef traits in Ireland. Livest. Sci. 99, 159-174.

Berry, D.P., Bermingham, M.L., Good, M. \& More, S.J., 2011. Genetics of animal health and disease in cattle. Irish Vet. J. $64,1-5$.

Carlén, E., Strandberg, E. \& Roth, A., 2004. Genetic parameters for clinical mastitis, somatic cell score, and production in the first three lactations of Swedish Holstein cows. J. Dairy Sci. 87, 3062-3070.

Hazel, L.N., 1943. The genetic basis for constructing selection indexes. Genetics 28, 476-490.

Ilatsia, E.D., Roessler, R., Kahi, A.K., Piepho, H.P. \& Zárate, A.V., 2011. Evaluation of basic and alternative breeding programs for Sahiwal cattle genetic resources in Kenya. Anim. Prod. Sci.51, 682-694.

Kahi, A.K. \& Nitter, G., 2004. Developing breeding schemes for pasture based dairy production systems in Kenya: I. Derivation of economic values using profit functions. Livest. Prod. Sci. 88, 161-177.

Kahi, A.K., Nitter, G. \& Gall, C.F., 2004. Developing breeding schemes for pasture based dairy production systems in Kenya: II. Evaluation of alternative objectives and schemes using a two-tier open nucleus and young bull system. Livest. Prod. Sci. 88, 179-192.

Kashongwe, O.B., Bebe, B.O., Huelsebusch, C.G. \& Matofari, J.W., 2017. Associations among milking practices, somatic cell counts and milk postharvest losses in smallholder dairy and pastoral camel herds in Kenya. Internat. J. Vet Sci. 5, 57-64.

Kosgey, I.S., Van Arendonk, J.A.M. \& Baker, R.L., 2003. Economic values for traits of meat sheep in medium to high production potential areas of the tropics. Small Rumin. Res. 50, 187-202.

Mbuthia, J.M., Rewe, T.O. \& Kahi, A.K., 2015. Breeding objectives for pigs in Kenya. II: economic values incorporating risks in different smallholder production systems. Trop. Anim. Health Prod. 47, 361-367.

Miglior, F., Muir, B.L. \& Van Doormaal, B.J., 2005. Selection indices in Holstein cattle of various countries. J. Dairy Sci. $88,1255-1263$.

Missanjo, E., Imbayarwo-Chikosi, V., \& Halimani, T., 2013. Estimation of genetic and phenotypic parameters for production traits and somatic cell count for Jersey dairy cattle in Zimbabwe. ISRN Vet. Sci. 2013, 1-5.

Mungube, E.O., Tenhagen, B.A., Regassa, F., Kyule, M.N., Shiferaw, Y., Kassa, T. \& Baumann, M.P.O., 2005. Reduced milk production in udder quarters with subclinical mastitis and associated economic losses in crossbred dairy cows in Ethiopia. Trop. Anim. Health Prod. 37, 503-512.

Nielsen, H.M., Christensen, L.G. \& Groen, A.F., 2005. Derivation of sustainable breeding goals for dairy cattle using selection index theory. J. Dairy Sci. 88, 1882-1890.

Nightingale, C., Dhuyvetter, K., Mitchell, R. \& Schukken, Y., 2008. Influence of variable milk quality premiums on observed milk quality. J. Dairy Sci. 91, 1236-1244.

Omore, A.O., McDermott, J.J., Arimi, S.M. \& Kyule, M.N., 1999. Impact of mastitis control measures on milk production and mastitis indicators in smallholder dairy farms in Kiambu district, Kenya. Trop. Anim. Health Prod.31, 347-361. 
Pfeiffer, C., Fuerst-Waltl, B., Schwarzenbacher, H., Steininger, F. \& Fuerst, C., 2015. A comparison of methods to calculate a total merit index using stochastic simulation. Genet. Sel. Evol. 47, 36-45.

Rewe, T.O., Indetie, D., Ojango, J.M.K. \& Kahi, A.K., 2006. Economic values for production and functional traits and assessment of their influence on genetic improvement in the Boran cattle in Kenya. J. Anim. Breed. Genet. 123, 23-36.

Rewe, T.O., Herold, P., Kahi, A.K. \& Zárate, A.V., 2011. Trait improvement and monetary returns in alternative closed and open nucleus breeding programs for Boran cattle reared in semi-arid tropics. Livest. Sci. 136, 122-135.

Ruegg, P.L. \& Pantoja, J.C.F., 2013. Understanding and using somatic cell counts to improve milk quality. Irish J. Agric. Food Res. 52, 101-117.

Sivarajasingam, S., 1995. A method to estimate economic weights for traits of disease resistance in sheep. Austr. Assoc. Adv. Anim. Breed. Genet. 11, 65-69.

Van Grevenhof, E.M., Van Arendonk, J.A. \& Bijma, P., 2012. Response to genomic selection: The Bulmer effect and the potential of genomic selection when the number of phenotypic records is limiting. Genet. Sel. Evol. 44, 26-36.

Visentin, G., McParland, S., De Marchi, M., McDermott, A., Fenelon, M.A., Penasa, M., Berry, D.P., 2017. Processing characteristics of dairy cow milk are moderately heritable. J. Dairy Sci. 100, 6343-6355.

Wagenaar, D., Van Arendonk, J., \& Kramer, J., 1995. Selection index program (SIP). User manual, version 1.0. Department of Animal Breeding, Agricultural University, Wageningen, The Netherlands.

Willam, A., Nitter, G., Bartenschlager, H., Karras, K., Niebel, E. \& Graser, H.U., 2008. ZPLAN, A computer program to optimise livestock selection schemes. User guide for ZPLAN+ 2007 (Z10). Hohenheim University, Stuttgart, Germany.

Wolfová, M., Wolf, J., Kvapilík, J. \& Kica, J., 2007. Selection for profit in cattle: I. Economic weights for purebred dairy cattle in the Czech Republic. J. Dairy Sci. 90, 2442-2455.

Zhao, L., Zhang, N., Li, S., Hu, H. \& Zhang, Y.W., 2014. Survey of somatic cell count, total bacterial count and protein in raw milk in Tangshan City, China. J. Food Agric. Environ. 12, 224-228. 
Appendix table 1 Estimates of phenotypes used to compute economic values for traits in the Kenyan breeding goal for dairy cattle

\begin{tabular}{|c|c|c|c|}
\hline Trait & Units & Symbols & Estimate \\
\hline \multicolumn{4}{|l|}{ Biological variables } \\
\hline Milk yield per cow per year & $\mathrm{kg}$ & MY & 3124.00 \\
\hline Fat yield per cow per year & $\mathrm{kg}$ & FY & 125.00 \\
\hline Protein yield per cow per year & $\mathrm{kg}$ & PY & 100.00 \\
\hline Age at first calving & days & AFC & 1016.00 \\
\hline Calving interval & days & $\mathrm{Cl}$ & 402.00 \\
\hline Pre-weaning daily gain & g/day & DG & 488.00 \\
\hline Post-weaning daily gain & g/day & PDG & 506.00 \\
\hline Mature live weight & $\mathrm{kg}$ & LW & 435.00 \\
\hline Pre-weaning survival rate & $\%$ & PSR & 0.93 \\
\hline Post-weaning survival rate & $\%$ & PWR & 0.93 \\
\hline Productive lifetime & days & PLT & 1893.00 \\
\hline \multicolumn{4}{|l|}{ Nutritional variables } \\
\hline Dry matter content in silage & $\%$ & sil & 15.00 \\
\hline Dry matter content in concentrates & $\%$ & conc & 89.00 \\
\hline Dry matter content in pasture & $\%$ & DMp & 20.00 \\
\hline Energy content in concentrates & $M J$ of $\mathrm{NE}_{\mathrm{L}}$ per $\mathrm{kg}$ & & 7.19 \\
\hline Energy content in pasture & $\mathrm{MJ}$ of $\mathrm{NE}_{\mathrm{L}}$ per $\mathrm{kg}$ & & 5.65 \\
\hline \multicolumn{4}{|c|}{$M J$ of $N_{L}$ : mega joules of net energy for lactation } \\
\hline \multicolumn{4}{|c|}{ Appendix table 2 Assumed costs (KES) for farm goods and services used in computation of economic values } \\
\hline Variable & Unit & symbol & Value ( KES) \\
\hline Price of milk per kg & $\mathrm{kg}$ & $\mathrm{pm}$ & 45.00 \\
\hline Price of fat per kg & $\mathrm{kg}$ & pf & 645.00 \\
\hline Price of protein & $\mathrm{kg}$ & $\mathrm{pp}$ & 800.00 \\
\hline Price of a calf & $\mathrm{kg}$ & $\mathrm{pc}$ & 3000.00 \\
\hline Price of live weight & $\mathrm{kg}$ & plw & 250.00 \\
\hline Cost of concentrates & $\mathrm{kg}$ & Pconc & 22.85 \\
\hline Price of silage & $\mathrm{kg}$ & psil & 14.00 \\
\hline Cost of pasture & $\mathrm{kg}$ & ppas & 16.67 \\
\hline Heifer health costs/head/day & head & cHhealth & 0.97 \\
\hline Cow health costs per head per year & head & CHcow & 3276.79 \\
\hline Cost of heifer reproduction per head per year & head & Cowrepch & 591.30 \\
\hline Labour costs per head per year & head & Clabour & 9.27 \\
\hline Cow labour costs per head per year & head & CLcows & 3383.55 \\
\hline Marketing costs per kg of milk & KES & mmilk & 2.25 \\
\hline Marketing costs per head for male calves & KES & mLW & 821.25 \\
\hline Calving rate & $\%$ & $\mathrm{cr}$ & 0.95 \\
\hline Heifer calf birth weight & $\mathrm{kg}$ & bw & 30.90 \\
\hline Survival rate to 24 hours of birth & $\%$ & Sr24 & 0.98 \\
\hline Period from birth to weaning & days & wa & 126.00 \\
\hline Period from weaning to 18 months & days & dwm & 414.00 \\
\hline Period from 18 months to first calving & days & dafc & 476.00 \\
\hline Weaning weight & $\mathrm{kg}$ & ww & 92.00 \\
\hline
\end{tabular}


Appendix table 3 Heritability (along diagonal bold), phenotypic standard deviations, economic values, genetic correlations (above diagonal) and phenotypic correlations (below diagonal) for traits in the breeding goal and selection criteria

\begin{tabular}{lrrrrrrrrrrrr}
\hline Traits & MY & FY & PY & SCC & AFC & Cl & DG & PDG & LW & SR1 & SR2 & PLT \\
\hline$\sigma_{p}$ & 1208.46 & 36.57 & 39.5 & 1.85 & 448.76 & 75.34 & 19.00 & 743.00 & 54.14 & 30.00 & 30.00 & 864.90 \\
MY & 0.30 & 0.75 & 0.70 & -0.03 & 0.20 & 0.17 & 0.10 & 0.11 & 0.23 & 0.00 & 0.00 & 0.00 \\
FY & 0.73 & 0.32 & 0.61 & -0.19 & -0.10 & 0.08 & 0.10 & 0.11 & 0.12 & 0.00 & 0.00 & 0.00 \\
PY & 0.95 & 0.78 & 0.34 & -0.02 & -0.14 & 0.10 & 0.00 & 0.00 & 0.13 & -0.20 & -0.20 & 0.16 \\
SCC & -0.20 & 0.02 & -0.13 & 0.09 & 0.00 & 0.17 & 0.00 & 0.00 & 0.00 & 0.00 & -0.13 & 0.06 \\
AFC & -0.21 & 0.05 & 0.22 & 0.00 & 0.38 & -0.21 & -0.20 & -0.20 & 0.15 & 0.00 & 0.00 & -0.13 \\
Cl & 0.17 & 0.08 & 0.00 & 0.00 & -0.21 & 0.06 & 0.00 & 0.00 & -0.40 & 0.00 & 0.00 & 0.10 \\
DG & 0.10 & 0.10 & 0.00 & 0.00 & -0.25 & 0.10 & 0.29 & -0.25 & 0.20 & 0.06 & 0.03 & 0.10 \\
PDG & 0.11 & 0.11 & 0.00 & 0.00 & -0.25 & 0.10 & 0.49 & 0.32 & 0.25 & 0.03 & 0.06 & 0.10 \\
LW & 0.23 & 0.12 & 0.06 & 0.00 & 0.15 & -0.43 & 0.40 & 0.47 & 0.30 & 0.01 & 0.00 & 0.27 \\
SR1 & 0.00 & 0.00 & 0.00 & 0.00 & 0.00 & 0.00 & 0.06 & 0.03 & 0.01 & 0.09 & 0.00 & 0.00 \\
SR2 & 0.00 & 0.00 & 0.11 & -0.14 & 0.00 & 0.00 & 0.03 & 0.06 & 0.00 & 0.01 & 0.09 & 0.00 \\
PLT & 0.00 & 0.00 & 0.00 & 0.00 & -0.13 & 0.10 & 0.10 & 0.10 & 0.27 & 0.00 & 0.00 & 0.11
\end{tabular}

MY: milk yield (kg); FY:fat yield (kg); PY: protein yield; SCC: somatic cell count; AFC: age at first calving (days); Cl: calving interval (days); DG: pre-weaning daily gain (g/day); PDG: post-weaning daily gain to 18 months (g/day); LW: live weight $(\mathrm{kg})$; SR1: pre-weaning survival rate (\%); SR2: post-weaning survival rate (\%); PLT: cow productive lifetime (days); op: phenotypic standard deviation

(Sources: Kahi et al., 2004; Kahi \& Nitter 2004; Ilatsia et al., 2011) 